\title{
Thymosin Modulation of Regulatory T Cell Function
}

\author{
Milton G. Mutchnick, Jorge A. Prieto, John A. Schaffner, and \\ Frederick E. Weller \\ Department of Medicine, University of Michigan and Veterans Administration Medical Centers, \\ Ann Arbor, Michigan 48105
}

\begin{abstract}
Fresh peripheral blood mononuclear cells (PBM) isolated from healthy human donors and activated with concanavalin $A$ (Con A) induced suppression of the proliferation response to Con $A$ in an allogeneic mixed leukocyte culture reaction (MLC). When PBM were incubated in media alone for $24 \mathrm{hr}$ prior to Con A activation of suppressor cells there was a significant decrease in the suppressive response. PBM incubated in the presence of thymosin for $24 \mathrm{hr}$ prior to Con A activation of the suppressor cells promoted a further augmentation of mitogen-induced proliferation. When PBM were incubated with thymosin in the absence of Con A activation of suppressor cells, enhancement of proliferation was observed in the MLC. These experiments suggest that thymosintreated PBM from healthy donors promote a helper rather than suppressive effect on mitogen-induced proliferation of allogeneic responder lymphocytes.
\end{abstract}

\section{INTRODUCTION}

Thymosin fraction 5, a polypeptide extract of calf thymus, can induce differentiation of human thymus-dependent $(\mathrm{T})$ lymphocytes (1-3). In addition, thymosin has been shown to modulate the functional capacity of differentiated $T$ cells which influence immunoregulatory control over $\mathrm{T}-\mathrm{T}$ and $\mathrm{T}-\mathrm{B}$ lymphocyte interactions (4-6). There is evidence to suggest that thymosin can modulate NK cell activity and decrease spontaneous cell-mediated cytotoxicity (7).

Thymosin is composed of at least 16 polypeptides with differing biological activities that can act individually, sequentially, or in concert on both pre-T and T-cell populations (3). A number of these peptides have been purified to homogencity and characterized chemically with sequence analysis. Several isolated peptides have been shown, in vitro, to induce either a helper effect (thymosin $\alpha_{5}$ ) or a suppressor effect (thymosin $\alpha_{7}$ ) (8).

Since thymosin fraction 5 contains polypeptides which can, at the same time, influence helper or suppressor activity, the present studies were undertaken to assess thymosin effect on both helper and suppressor activity of peripheral blood lymphocytes from healthy human adults.

\section{MATERIALS AND METHODS}

Separation of peripheral blood mononuclear cells $(P B M)$. Peripheral venous blood from 35 healthy laboratory and medical personnel ( 27 males, 8 females: ages 21-60 years, $34.6 \pm 2.0 \mathrm{SEM}$ years) was drawn into plastic syringes containing preservative-free heparin. Donors were excluded when there was a history of malignancy, known immunodeficiency, recent viral upper respiratory illness, or blood transfusion within 3 months of the evaluation. The blood was diluted v:v in 
$\mathrm{Ca}^{2+}$ - and $\mathrm{Mg}^{2+}$-free $\mathrm{HBSS}$ containing $0.35 \mathrm{~g}$ of $\mathrm{Na}_{2} \mathrm{HCO}_{3}$ per liter. The diluted blood was layered in 25-ml aliquots onto $9 \mathrm{ml}$ of Ficoll-Hypaque gradient (Pharmacia Fine Chemicals, Piscataway, N.J.) and centrifuged at $400 \mathrm{~g}$ for $40 \mathrm{~min}$ at room temperature. The cells at the interface were removed, washed with HBSS, and centrifuged at $400 \mathrm{~g}$ for $15 \mathrm{~min}$. The cells were washed twice more, centrifuged at $300 \mathrm{~g}$ for $10 \mathrm{~min}$, and resuspended at a concentration of $5 \times 10^{6} \mathrm{PMB} / \mathrm{ml}$ in RPMI-1640 medium (GIBCO, Grand Island, N.Y.) enriched with vitamins, $2 \mathrm{mM}$ glutamine, penicillin $(100 \mathrm{units} / \mathrm{ml})$, streptomycin $(100 \mu \mathrm{g} / \mathrm{ml})$, and $10 \%$ heatinactivated fetal calf serum (complete medium).

Thymosin. Purified bovine thymosin fraction 5, generously provided by Dr. A. L. Goldstein (George Washington University Medical Center, Washington, D.C.), was prepared (9) and stored at $-20^{\circ} \mathrm{C}$. Concentrations ranging from 50 to $400 \mu \mathrm{g} / \mathrm{ml}$ in complete medium were used. Spleen fraction 5, used as a control for nonspecific biological activity in the thymosin preparation, was prepared in an identical manner at $200 \mu \mathrm{g} / \mathrm{ml}$.

Suppressor and helper activity. To measure suppressor and/or helper activity promoted by thymosin in the presence or absence of Con A (Pharmacia Fine Chemicals), an MLC was used $(10,11)$. In the initial culture, either 0 or $20 \mu \mathrm{g}$ of thymosin in a constant volume $(0.1 \mathrm{ml})$ of complete medium was added to $1 \mathrm{ml}$ of the PBM suspension in plastic tubes and incubated at $37^{\circ} \mathrm{C}$ for $24 \mathrm{hr}$ in a humidified $5 \% \mathrm{CO}_{2}$ and air atmosphere. Parallel tubes containing $1 \mathrm{ml}$ of the PBM suspension plus $0.1 \mathrm{ml}$ of complete medium only were prepared for immediate use. The final volume in each tube was $1.1 \mathrm{ml}$. Following the 0 or $24-\mathrm{hr}$ period of incubation, the PBM were resuspended and $0.55 \mathrm{ml}$ of each tube was incubated in the presence or absence of Con A ( $5 \mu \mathrm{g} / \mathrm{ml})$ for an additional $48 \mathrm{hr}$. These constituted the 2 day and 3 day initial cultures, respectively. After incubation the control and Con A activated cells were treated with $50 \mu \mathrm{g} / \mathrm{ml}$ of mitomycin C (Sigma Chemical Co., St. Louis, Mo) for $30 \mathrm{~min}$, washed twice in $30 \mathrm{~m} M \alpha$ methylmannoside in phosphate-buffered saline to remove any residual Con $\mathrm{A}$, and once again in complete medium. The PBM were resuspended in complete medium at $1 \times 10^{6} \mathrm{cells} / \mathrm{ml}$.

Fresh PBM (responder cells) from a healthy donor were adjusted to $2 \times 10^{6}$ cells $/ \mathrm{ml}$ in complete medium. For the coculture experiments, PBM from the 2 day or 3 day initial cultures were incubated with fresh allogeneic responder cells obtained from the same donor for $90 \mathrm{hr}$. The studies were performed in the wells of flat bottom microtiter plates (Costar, Cambridge, Mass.) to which were added $0.05 \mathrm{ml}$ of responder PBM $\left(1 \times 10^{5}\right.$ cells $), 0.1 \mathrm{ml}$ of precultured PBM $\left(1 \times 10^{5}\right.$ cells), and $0.05 \mathrm{ml}$ of complete medium containing Con A ( $40 \mu \mathrm{g})$. In control wells $0.05 \mathrm{ml}$ of complete medium without Con $\mathrm{A}$ was added such that the total volume in each well was $0.2 \mathrm{ml}$. In some experiments spleen fraction 5 was also used in the same manner as thymosin. Tritiated thymidine, $2 \mu \mathrm{Ci}$ per well (New England Nuclear, Waltham, Mass.), was added $18 \mathrm{hr}$ prior to harvesting with an automatic multiple sample harvester (Otto Hiller Co., Madison, Wisc.). The incorporation of $\left[{ }^{3} \mathrm{H}\right\rfloor$ thymidine into cells was measured in a Beckman liquid scintillation system.

Dose-response to thymosin. In some experiments, thymosin was added at final concentrations in the tubes of $5,10,20$, and $40 \mu \mathrm{g} / \mathrm{ml}$ to determine the optimal 
concentration for use in the Con A-induced suppressor cell assay. The effect of thymosin alone on Con A-stimulated blast formation of responder cells was evaluated by omitting Con $\mathrm{A}$ in the initial cultures. Culture conditions for these studies were identical to those described above.

Lose of suppressor activity with preincubation. Recent studies have reported a loss of Con A-induced suppressor activity when PBM in the initial culture are incubated for $24 \mathrm{hr}$ prior to activation with Con A (12-14). The influence of a 24-hr preincubation period on suppressor activity was determined to assess in vitro loss of suppressor cell activity (SCA) and to evaluate the suppressor cell response to preincubation in the presence of thymosin.

Calculation of helper/suppressor activity. The data were determined as mean counts per minute (cpm) from quadruplicate cultures. The percentage suppression of responder cells by PBM from the 2 day and 3 day initial cultures not containing thymosin was expressed as $1-(\Delta \mathrm{cpm}$ suppressor cells $/ \Delta \mathrm{cpm}$ control cells $) \times 100$; where $\Delta \mathrm{cpm}=\mathrm{cpm}$ of Con A stimulated cocultures $-\mathrm{cpm}$ unstimulated cocultures; suppressor $=$ Con A activated PBM from initial cultures; control = PBM not activated with Con $A$ in initial cultures. The percentage suppression induced by treatment with thymosin or spleen fraction 5 in the 3 day initial cultures was calculated as $1-(\Delta \mathrm{cpm}$ pretreated suppressor cells/ $\Delta \mathrm{cpm}$ control cells $) \times 100$. The effect of thymosin alone, in the absence of Con $\mathrm{A}$ induction in the initial cultures, was determined as $1-(\Delta \mathrm{cpm}$ thymosin pretreated PBM/ $\Delta \mathrm{cpm}$ nontreated $\mathrm{PBM}) \times 100$. A positive value reflected suppression of blast transformation in allogeneic responder cells and a negative value indicated enhancement of responder cell transformation. The significance of the modulation in MLC response induced by Con A or thymosin was determined using Student's paired $t$ test.

\section{RESULTS}

\section{Determination of Optimal Thymosin Effect}

A dose-response curve for thymosin was performed with six subjects and maximum suppression of allogeneic responder cells was seen at thymosin concentrations of 10 and $20 \mu \mathrm{g} / \mathrm{ml}$. The effect of thymosin alone on the suppressive function of PBM was determined by omitting Con A from the initial cultures. A dose-response to thymosin was observed with enhancement rather than suppression of $\left[{ }^{3} \mathrm{H}\right]$ thymidine incorporation by Con A-stimulated responder cells. Maximum enhancement was observed at concentrations of 10 and $20 \mu \mathrm{g} / \mathrm{ml}$. A concentration of $20 \mu \mathrm{g} / \mathrm{ml}$ thymosin was therefore used for the remaining experiments. To determine if thymosin could exert a mitogenic effect, PBM from eight subjects were incubated for $72 \mathrm{hr}$ with $0,5,10$, and $20 \mu \mathrm{g} / \mathrm{ml}$ of thymosin. No mitogenic effect was observed with mean $\mathrm{cpm} \pm \mathrm{SEM}$ of $453 \pm 68,482 \pm 64,450$ \pm 48 , and $496 \pm 47$, respectively.

\section{Con A-Induced SCA}

For the 35 subjects, the mean cpm $( \pm$ SEM) in the Con A-stimulated MLC. containing control PBM from the 2 day initial cultures was $90,390 \pm 5,385$. Similarly the cpm in the MLC-containing control PBM from the 3 day cultures was 
$93,173 \pm 4,444$. The percentage suppression of fresh allogeneic responder cells by PBM from the 2 day and 3 day initial cultures not treated with thymosin are shown in Table 1. There was a significant decrease in SCA when PBM in the initial cultures were incubated for $24 \mathrm{hr}$ prior to Con A activation ( 3 day culture). The results with spleen fraction 5 in the 21 subjects evaluated were similar to that seen in the 3 day cultures containing untreated suppressor PBM (Table 1).

In the 3 day initial cultures where suppressor but not control PBM were incubated with thymosin for $24 \mathrm{hr}$, significantly less suppression was observed than in parallel cultures containing suppressor PBM incubated in the absence of this modulator (Table 1). Examination of the individual responses showed that in the presence of thymosin, 11 of 35 subjects ( 9 males, 2 females; $39.8 \pm 4.0$ years) had a mean absolute increase of $9.5 \pm 2.4 \%( \pm \mathrm{SEM})$ in suppression over the values observed in parallel untreated cultures. In contrast, the remaining 24 subjects ( 18 males, 6 females; $32.2 \pm 2.1$ years) showed enhancement with a decrease in suppression of $13.8 \pm 2.7 \%$. When the values for suppressor activity seen in the untreated 3 day initial cultures were stratified according to thymosin-induced increases or decreases in SCA observed in parallel cultures, the values obtained were $-0.7 \pm 3.8 \%$ (11 subjects) and $9.8 \pm 2.7 \%$ (24 subjects), respectively $(P<$ 0.05 ). Although the 11 subjects tended to be older, the difference in age was not statistically significant.

These experiments suggested that thymosin promoted a helper effect in a majority (24) of normal subjects. This supposition was confirmed in experiments in which Con A was omitted from the 3 day initial cultures treated with thymosin. Enhancement rather than suppression of Con A-stimulated blast transformation of responder cells was observed $(-7.3 \pm 3.0 \% ; 35$ subjects $)$.

\section{Thymosin Effect on Helper/Suppressor Activity}

In order to determine thymosin effect on Con A-induced SCA in the presence of a simultaneous influence on helper activity, the percentage suppression of the responder cells by thymosin pretreated suppressor cells was calculated using controls also pretreated with thymosin. Under these conditions, the percentage suppression did not differ significantly from the values obtained with the untreated suppressor cells from the 3 day initial cultures (Table 1).

We examined the possibility that the decrease in suppression seen when the Con A activated PBM were pretreated with thymosin was the result of a thymosin-induced helper effect rather than a thymosin-promoted decrease in SCA. If such were the case, we could predict that the difference $(\Delta)$ between the percentage of suppression seen in initial cultures where both the suppressor and control cells were pretreated with thymosin and, initial cultures where the suppressor but not the control cells were incubated with thymosin would be comparable to the enhancement obtained in the MLC where PBM from the initial cultures were pretreated with thymosin, but not activated with Con A. The Pearson product-moment correlation test was used to ascertain coefficients of correlation and the related $P$ value when comparing the predicted $\Delta$ in percentage suppression to the actual percentage suppression induced by PBM treated with thymosin but not activated by Con A. As shown in Table 2, there was a significant correlation between the predicted and actual values $(r=0.8834, P<0.001)$. 


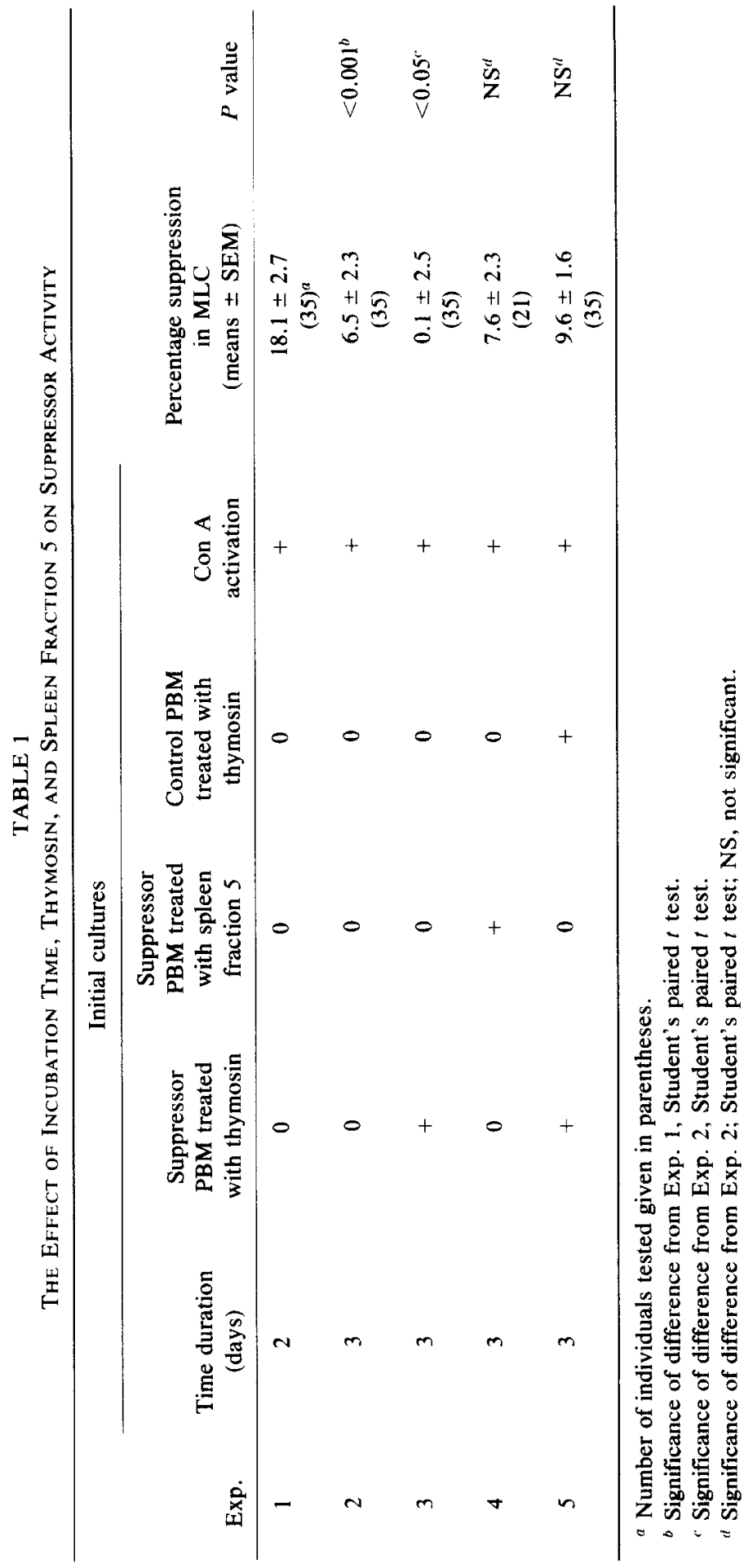


TABLE 2

Thymosin Effect on Helper Activity in 3 Day Initial Cultures

(Mean Percentage Suppression \pm SEM in MLC) ${ }^{a}$

\begin{tabular}{|c|c|c|c|}
\hline \multirow{2}{*}{$\begin{array}{l}\text { (A) } \\
\text { Suppressor and control } \\
\text { cells treated with thymosin }{ }^{b}\end{array}$} & \multirow{2}{*}{$\begin{array}{l}\text { (B) } \\
\text { Suppressor cells only } \\
\text { treated with thymosin }\end{array}$} & \multicolumn{2}{|c|}{$\begin{array}{l}(C) \\
\text { PBM treated with } \\
\text { thymosin }\end{array}$} \\
\hline & & $\begin{array}{l}\text { Predicted } \\
\qquad(\Delta)^{\prime \prime}\end{array}$ & Actual \\
\hline 10.8 & 7.5 & -3.3 & -3.7 \\
\hline 9.7 & 5.6 & -4.1 & -4.5 \\
\hline 2.5 & -21.6 & -24.1 & -24.7 \\
\hline 3.9 & -16.2 & -20.1 & -7.0 \\
\hline 10.3 & 8.9 & -1.4 & -1.5 \\
\hline-6.8 & 17.3 & 24.1 & 22.6 \\
\hline 24.9 & -1.3 & -26.2 & -34.8 \\
\hline 20.0 & 3.5 & -16.5 & -20.7 \\
\hline 11.9 & 19.7 & 7.8 & -13.9 \\
\hline 19.2 & 6.9 & -12.3 & -15.2 \\
\hline 14.1 & -12.6 & 26.7 & -17.8 \\
\hline 12.6 & 12.3 & -0.3 & -0.3 \\
\hline 17.5 & -23.1 & -40.6 & -35.8 \\
\hline 14.2 & -6.1 & -20.3 & -23.6 \\
\hline 4.4 & 12.3 & 7.9 & 8.3 \\
\hline 16.6 & 10.5 & -6.1 & -7.3 \\
\hline 11.6 & -50.2 & -61.8 & -69.7 \\
\hline 5.1 & -5.9 & -11.0 & 4.2 \\
\hline 9.3 & 3.9 & -5.4 & -6.0 \\
\hline 8.8 & -5.5 & -14.3 & -14.2 \\
\hline-1.4 & -4.9 & -3.5 & -3.5 \\
\hline 1.2 & -7.2 & -8.4 & -0.8 \\
\hline-9.2 & -17.7 & -8.5 & -7.8 \\
\hline 21.8 & 5.1 & -16.7 & -13.0 \\
\hline 8.8 & 4.6 & -4.2 & 3.8 \\
\hline 1.9 & 0.0 & -1.9 & -2.0 \\
\hline 19.6 & 21.9 & 2.3 & 17.9 \\
\hline 26.3 & 15.8 & -10.4 & 11.9 \\
\hline-15.5 & 1.5 & 17.0 & 14.7 \\
\hline 13.9 & 8.5 & -4.4 & -6.3 \\
\hline 3.4 & -9.6 & -13.0 & 3.4 \\
\hline 3.6 & -10.7 & -14.3 & -14.8 \\
\hline 12.0 & 6.4 & -5.6 & 0.6 \\
\hline 9.8 & 25.3 & 13.5 & 17.2 \\
\hline 20.6 & -2.0 & -22.6 & -11.9 \\
\hline 9.6 & 0.1 & -9.6 & -7.3 \\
\hline SEM & 2.5 & $\begin{aligned} & 2.7 \\
r= & 0.8834 \\
P & <0.001\end{aligned}$ & 2.9 \\
\hline
\end{tabular}

\footnotetext{
"The values observed in the 35 subjects are listed.

"After preincubation for $24 \mathrm{hr}$ with thymosin, the suppressor cells were activated with Con A for an additional $48 \mathrm{hr}$. Suppressor and control cells were then added to the MLC.

PBM preincubated with thymosin for $24 \mathrm{hr}$ and PBM preincubated for $24 \mathrm{hr}$ in the absence of thymosin were incubated an additional $48 \mathrm{hr}$ in the absence of Con A and added to the MLC.

"Values represent the arithmetic difference in B from A, computed for each subject.
} 


\section{DISCUSSION}

The experiments in this study indicate that thymosin modulates a predominantly helper effect on normal human peripheral blood $\mathrm{T}$ cells with no apparent effect on the ability of Con A to induce SCA. Thymosin-pretreated PBM activated with Con $A$ increased suppression in only 11 subjects. However, these individuals had a significantly lower baseline suppressor activity in the untreated 3 day initial cultures than did the remaining 24 subjects. Thus, thymosin modulated an increase in SCA in individuals with low baseline suppressor activity and a decrease in SCA in subjects with higher baseline suppressor activity. This modulation of helper/suppressor activity parallels the balancing effect of thymosin on in vitro $\mathrm{T}$ cell counts in normal subjects as described previously (15). Thymosin appears to restore balance in cellular immune function rather than serving to promote a hyperimmune state. In a previous report utilizing the experimental systems outlined in this study, thymosin significantly increased Con A-induced SCA in patients with chronic active hepatitis who were also shown to have markedly decreased baseline suppressor activity (16). Similar findings were reported in patients with systemic lupus erythematosus (10).

In the present study, the addition of Con A to PBM pretreated with thymosin did not augment the helper or suppressor effect seen with thymosin alone. While these observations conflict with previous reports of Con A augmenting thymosin effect $(4,10)$, it is apparent from the present series of experiments that Con $A$ unmasked the equivalent suppressor activity in thymosin-pretreated PBM to that observed in cultures containing Con A-induced suppressor cells not treated with thymosin. We, like others (4), did not observe a blocking effect by thymosin to Con $\mathbf{A}$ induction of suppressor cells as previously reported (17).

The proliferative response of human PBM appears to increase when the latter are incubated prior to stimulation with Con $A(13,14)$. It has been suggested that this represents a loss of short-lived suppressor cells during the preincubation period $(13,14,18)$. Recently, thymosin was shown to decrease this augmentation of proliferation presumably by inducing differentiation of a suppressor cell from a precursor population (6). In the present study, the responses observed in the 2 day initial cultures were monitored in the 35 subjects to assess the suppressor cell depletion seen in the 3 day initial cultures where PBM were incubated for $24 \mathrm{hr}$ in the presence or absence of thymosin. In the absence of thymosin, 25 subjects (19 males, 6 females; $36.5 \pm 2.3$ years) showed augmentation of proliferation in the MLC after a $24 \mathrm{hr}$ preincubation. In the remaining 10 subjects ( 8 males, 2 females; $29.8 \pm 3.5$ years), one showed no change and 9 showed an increase in suppression. Thymosin pretreatment further increased suppression in only 3 of 9 individuals in the latter group and resulted in augmentation in the remaining 6 subjects. Of the 25 subjects showing augmentation in the absence of thymosin, pretreatment with thymosin decreased or abolished the proliferative response in only 4 while further increasing augmentation in 16 . No change in proliferative response was seen in the remaining 5 subjects. There was no correlation between the individual responses to thymosin and age or sex in this group of 35 healthy subjects. Thus, we were not able to confirm previous reports that thymosin can induce differentiation of a suppressor cell from precursors in normal individuals. It is possible that there are 
too few precursor suppressor cells in normal individuals which will differentiate into suppressor cells with thymosin treatment. Alternatively, PBM preincubated for $24 \mathrm{hr}$ may not suffer a loss in SCA but instead may promote changes in the self regulatory dynamics of the responder cells $(18,19)$. It has been suggested that Con A does not generate suppressor cell activity in initial cultures, rather Con Atreated PBM may provide "less help" in the normal enhancement of responder cells usually observed when fresh allogeneic PBM are added (19).

In the present study, the influence of thymosin on helper/suppressor effect in the presence of Con A activation may reflect a summation phenomenon. That is, the specific peptides in thymosin that induce help or suppression can directly influence regulatory status which in turn is dependent on the exact balance of $T$ cell subsets, and perhaps monocytes, in the PBM suspensions. To this is added the known effect of Con A on regulatory $T$ cell numbers and function (20). It is clear, however, that thymosin alone can promote helper function by PBM isolated from healthy human subjects.

\section{ACKNOWLEDGMENTS}

This work was supported by the Veterans Administration and by an NIH Biomedical Research Support Grant RR05083.

\section{REFERENCES}

1. Schulof, R. S., and Goldstein, A. L., Adv. Int. Med. 22, 121, 1977.

2. Goldstein, A. L., Thurman, G. B., Cohen, H., and Hooper, J. A., In "Molecular Approaches to Immunology"' (E. E. Smith and D. W. Ribbons, Eds.), pp. 243-265, Academic Press, New York, 1975.

3. Low, 'I. L. K., Thurman, G. B., Chincarini, C., McClure, J. E., Marshall, G. D., Hu, S. K., and Goldstein, A. L., Ann. N.Y. Acad. Sci. 332, 33, 1979.

4. Kaufman, D. B., Clin. Exp. Immunol. 39, 722, 1980.

5. Wolf, R. E., Goldstein, A. L., and Ziff, M., Clin. Immunol. Immunopathol. 11, 303, 1978.

6. Wolf, R. E., J. Clin. Invest. 63, 677, 1979.

7. Mutchnick, M. G., Missirian, A., and Johnson, A. G., Clin. Immunol. Immunopathol. 16, 423, 1980.

8. Ahmed, A., Wong, D. M., Thurman, G. B., Low, T. L. K., Goldstein, A. L., Sharkis, S. J., and Goldschneider, I., Ann. N.Y. Acad. Sci. 332, 81, 1979.

9. Hooper, J. A., McDaniel, M. C., Thurman, G. B., Cohen, G. H., Schulof, R. S., and Goldstein, A. L., Ann. N.Y. Acad. Sci. 249, 125, 1975.

10. Horowitz, S., Borcherding, W., Vishnu Moorthy, A., Chesney, B., Schulte-Wissermann, H., and Hong, R., Science 197, 999, 1977.

11. Shou, L., Schwartz, S. A., and Good, R. A., J. Exp. Med. 143, $1100,1976$.

12. Dwyer, J. M., Johnson, C., and Desaules, M., Clin. Exp. Immunol. 38, 499, 1979.

13. Feighery, C., Whelan, C. A., Weir, D. G., and Greally, J. F., Clin. Exp. Immunol. 32, 459, 1978.

14. Bresnihan, G., and Jasin, H. E., J. Clin. Invest. 59, 106, 1977.

15. Chretien, P. B., Lipson, S. D., Makuch, R. W., Kenady, D. E., and Cohen, M. H., Ann. N.Y. Acad. Sci. 332, 135, 1979.

16. Schaffner, J. A., Mutchnick, M. G., and Goldstein, A. L., Gastroenterology 77, A-39, 1979.

17. Serrou, B., Rosenfeld, C., Caroux, J., Theirry, C., Cupissol, D., and Goldstein, A. L., Ann. N.Y. Acad. Sci. 332, 95, 1979.

18. Schwartz, S. A., Shou, L., Good, R. A., and Choi, S., Proc. Nat. Acad. Sci. USA 74, 2099, 1977.

19. Fernandez, I.. A., and Macsween J. M., J. Immunol. 125, 267, 1980.

20. Gupta, S., Schwartz, S. A., and Good, R. A., Cell. Immunol. 44, 242, 1979.

Received October 2, 1981; accepted with revisions December 22, 1981. 